\title{
Atmospheric iron supply and marine productivity in the glacial North Pacific Ocean
}

\author{
François Burgay $^{1,2}$, Andrea Spolaor ${ }^{1}$, Jacopo Gabrieli $^{1}$, Giulio Cozzi ${ }^{1}$, Clara Turetta ${ }^{1}$, Paul Vallelonga ${ }^{3,4}$, and \\ Carlo Barbante ${ }^{1,2}$ \\ ${ }^{1}$ Institute of Polar Sciences, National Research Council, Via Torino 155, 30170 Venice, Italy \\ ${ }^{2}$ Department of Environmental Sciences, Informatics and Statistics, Ca' Foscari University of Venice, \\ Via Torino 155, 30170 Venice, Italy \\ ${ }^{3}$ Physics of Ice Climate and Earth, Niels Bohr Institute, University of Copenhagen, \\ Tagensvej 16, Copenhagen N2200, Denmark \\ ${ }^{4}$ Oceans Graduate School, University of Western Australia, 64 Fairway, Crawley, WA 6009, Australia
}

Correspondence: Andrea Spolaor (andrea.spolaor@unive.it)

Received: 3 June 2020 - Discussion started: 10 July 2020

Revised: 13 January 2021 - Accepted: 14 January 2021 - Published: 23 February 2021

\begin{abstract}
Iron $(\mathrm{Fe})$ is a key element in the Earth climate system, as it can enhance marine primary productivity in the high-nutrient low-chlorophyll (HNLC) regions where, despite a high concentration of major nutrients, chlorophyll production is low due to iron limitation. Eolian mineral dust represents one of the main Fe sources to the oceans; thus, quantifying its variability over the last glacial cycle is crucial to evaluate its role in strengthening the biological carbon pump. Polar ice cores, which preserve detailed climate records in their stratigraphy, provide a sensitive and continuous archive for reconstructing past eolian Fe fluxes. Here, we show the Northern Hemisphere Fe record retrieved from the NEEM ice core (Greenland), which offers a unique opportunity to reconstruct the past Fe fluxes in a portion of the Arctic over the last $108 \mathrm{kyr}$. Holocene Fe fluxes (0.042$11.7 \mathrm{ka}, 0.5 \mathrm{mg} \mathrm{m}^{-2} \mathrm{yr}^{-1}$ ) at the NEEM site were 4 times lower than the average recorded over the last glacial period (11.7-108 ka, $2.0 \mathrm{mg} \mathrm{m}^{-2} \mathrm{yr}^{-1}$ ), whereas they were greater during the Last Glacial Maximum (LGM; 14.5-26.5 ka, $3.6 \mathrm{mg} \mathrm{m}^{-2} \mathrm{yr}^{-1}$ ) and Marine Isotope Stage 4 (MIS 4; 60$71 \mathrm{ka}, 5.8 \mathrm{mg} \mathrm{m}^{-2} \mathrm{yr}^{-1}$ ). Comparing the NEEM Fe record with paleoceanographic records retrieved from the HNLC North Pacific, we found that the coldest periods, characterized by the highest Fe fluxes, were distinguished by low marine primary productivity in the subarctic Pacific Ocean, likely due to the greater sea ice extent and the absence of major nutrients upwelling. This supports the hypothesis that $\mathrm{Fe}$
\end{abstract}

fertilization during colder and dustier periods (i.e., LGM and MIS 4) was more effective in other regions, such as the midlatitude North Pacific, where a closer relationship between marine productivity and the NEEM Fe fluxes was observed.

\section{Introduction}

Greenland and Antarctic ice cores are unique archives that can provide records of temperature, atmospheric dust load and atmospheric gas composition variability during the Holocene and the late Pleistocene (Jouzel et al., 1996; Lambert et al., 2008; Schüpbach et al., 2018; Watanabe et al., 2003). Glacial periods were dustier and were characterized by a lower $\mathrm{CO}_{2}$ concentration $(\approx 180 \mathrm{ppm})$ than interglacials ( $\approx 280$ ppm) (Lambert et al., 2008; Lüthi et al., 2008). This dichotomy is explained through several different hypotheses: the increase in aridity and newly exposed continental shelves (Fuhrer et al., 1999), an increase in the aerosol atmospheric lifetime resulted from a reduced hydrological cycle (Lambert et al., 2008; Yung et al., 1996), increased glacial-derived mobilization of highly bioavailable iron ( $\mathrm{Fe})$ from physical breakdown of bedrock (Shoenfelt et al., 2018), and, lastly, more vigorous polar circulation capable of entraining additional dust from lower latitudes (Mayewski et al., 1994). Regardless of the source, the higher atmospheric burden of mineral dust during glacial periods affected climate through 
both physical and biological mechanisms. Dust particles can directly influence the Earth's radiative budget by scattering, absorbing and re-emitting shortwave and longwave radiation (Miller and Tegen, 1998; Schepanski, 2018). During the Last Glacial Maximum (LGM), model results showed that the enhanced dust transport alone caused a $1.0 \mathrm{~W} \mathrm{~m}^{-2}$ globally averaged radiative forcing decrease compared with presentday conditions, which contributed to a $0.85^{\circ} \mathrm{C}$ cooling relative to the current climate (Mahowald et al., 2006). Conversely, once deposited on the ocean surface, the mineral dust delivered major and micronutrients (including $\mathrm{Fe}$ ) that could have stimulated the biological carbon pump (Martin et al., 1990). Indeed, Fe can limit marine primary production (MPP) in the high-nutrient low-chlorophyll (HNLC) oceans, which are characterized by a high concentration of nutrients but low productivity (Martin et al., 1990). The largest (HNLC) oceans are the Southern Ocean, the equatorial Pacific and the North Pacific Ocean (Duggen et al., 2010). In these regions, the $\mathrm{Fe}$ role in modulating marine productivity has been demonstrated through both artificial Fe fertilization experiments (Smetacek et al., 2012; Tsuda et al., 2003; Yoon et al., 2018) and natural Fe inputs from iceberg melting, volcanic eruptions and glacially sourced dust (Duprat et al., 2016; Langmann et al., 2010; Shoenfelt et al., 2017). For its biological relevance, it has been hypothesized that the recorded decrease in the atmospheric $\mathrm{CO}_{2}$ concentration during glacial periods was linked to the Fe-modulated enhancement of the biological carbon pump in the HNLC regions due to the increase in $\mathrm{Fe}$ availability (Martin et al., 1990). Evidence of the existence of a strong link between atmospheric Fe deposition and marine productivity was retrieved from a marine sediment core collected in the subantarctic zone of the Southern Ocean, where the coldest periods were mirrored by an increase in atmospheric Fe fluxes and by an enhancement in both MPP and the degree of nutrient consumption (Martínez-García et al., 2014). Yet, according to both modeling (Lambert et al., 2015) and observational (Gaspari et al., 2006; Röthlisberger et al., 2004; Vallelonga et al., 2013) studies, the Fe fertilization mechanism itself cannot completely explain the $\approx 100$ ppmv glacial-interglacial atmospheric $\mathrm{CO}_{2}$ variability, only accounting for around 820 ppmv of it (Lambert et al., 2015).

However, the role of Fe fertilization in the Northern Hemisphere and in the HNLC region of the North Pacific is unclear due to the few available Arctic Fe flux records, which are either limited to the last century or only cover short time periods (Burgay et al., 2019; Hiscock et al., 2013). Thus, reconstructing how the Fe concentrations and fluxes have changed in the Northern Hemisphere during the last glacial cycle is essential in order to understand the evolution of the global atmospheric circulation, the human impact on dust mobilization (Mahowald et al., 2008) as well as to evaluate the impact that Fe might have had on MPP in the North Pacific HNLC region. Here, we present a high-resolution $108 \mathrm{kyr}$ record of total dissolvable $\mathrm{Fe}$ (TDFe) retrieved from the North Green-

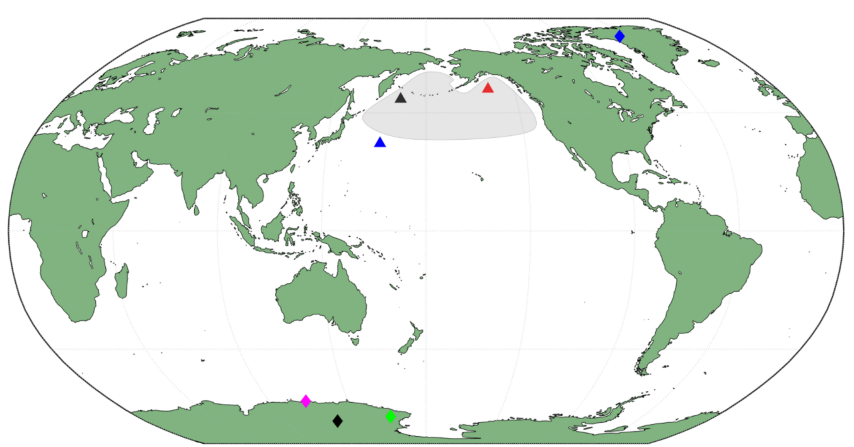

Figure 1. Location of the NEEM ice core (blue diamond; this study), the LD ice core (pink triangle; Edwards et al., 2006), the EDC ice core (black diamond; Wolff et al., 2006) and the TD ice core (green diamond; Vallelonga et al., 2013). We retrieved paleoproductivity data for the eastern North Pacific (black triangle) from the ODP882 (Haug et al., 1995) and SO202-27-6 (Méheust et al., 2018) sediments cores, and we retrieved these data for the western Pacific Ocean (red triangle) from the ODP887 (McDonald et al., 1999) and SO202-07-6 (Méheust et al., 2018) sediment cores. The paleoproductivity record from the midlatitude North Pacific was retrieved from the S-2 sediment core (blue triangle; Amo and Minagawa, 2003).

land Eemian Ice Drilling (NEEM) ice core (Rasmussen et al., 2013; Schüpbach et al., 2018), which provides a unique insight into the atmospheric Fe supply in the Arctic both during the Holocene and the last glacial period. Furthermore, we performed a comparison between the TDFe NEEM record and various paleoproductivity records from the HNLC North Pacific region (Fig. 1) to evaluate whether the increase in eolian $\mathrm{Fe}$ fluxes was mirrored by an increase in marine productivity. We underline that the TDFe concentration, as it will be discussed in the following, derives from the acidification of the snow samples for 1 month at $\mathrm{pH} 1$. Thus, the values represent an upper limit of the eolian Fe potentially available for the phytoplankton, and they might overestimate the actual bioavailable Fe.

\section{Materials and methods}

\subsection{Sampling and processing}

In the framework of the NEEM project, a $2540 \mathrm{~m}$ deep ice core was drilled in northwestern Greenland $\left(77^{\circ} 45^{\prime} \mathrm{N}\right.$, $\left.51^{\circ} 06^{\prime} \mathrm{W}\right)$ at $2479 \mathrm{~m}$ a.s.l. The site is characterized by an average annual temperature of $-29^{\circ} \mathrm{C}$ and a modern accumulation of $22 \mathrm{~cm}$ ice equivalent per year. According to the GICC05modelext-NEEM-1 timescale, the ice core covers the last $128 \mathrm{kyr}$ (Rasmussen et al., 2013). The ice cores were cut to obtain ice sticks with a square cross section of $36 \mathrm{~mm} \times 36 \mathrm{~mm}$. They were continuously melted on a continuous flow analysis (CFA) system with a typical melt speed of $3.5 \mathrm{~cm} \mathrm{~min}^{-1}$ (Schüpbach et al., 2018). The CFA system provides meltwater from the inner and least likely to be con- 
Table 1. Temporal resolution of the NEEM ice core in accordance with the GICC05modelext-NEEM-1 age scale (Rasmussen et al., 2013). Ice samples for ICP-MS analysis were collected with a resolution of $110 \mathrm{~cm}$.

\begin{tabular}{ll}
\hline $\begin{array}{l}\text { Temporal } \\
\text { resolution }\end{array}$ & Period \\
\hline 10 years & Holocene (present-7.2 ka) \\
22 years & Holocene $(7.2$ ka-LGM) \\
110 years & Last Glacial Maximum \\
73 years & Interstadials \\
147 years & $28-59 \mathrm{ka}$ \\
440 years & $59-70 \mathrm{ka}$ \\
220 years & $70-96 \mathrm{ka}$ \\
730 years & $96-110 \mathrm{ka}$ \\
\hline
\end{tabular}

taminated part of the core; thus, we did not adopt any further decontamination procedure. The inductively coupled plasma mass spectrometry (ICP-MS) samples were manually collected at a low resolution $(110 \mathrm{~cm})$. The temporal resolution depends on the accumulation rate and decreases with depth because of the ice thinning. According to the available timescale (Rasmussen et al., 2013) and considering the $110 \mathrm{~cm}$ sampling resolution, the temporal resolution varies from decadal to millennial (Table 1).

Samples were collected in vials that had been previously cleaned as follows: stored in $\mathrm{HNO}_{3} 5 \%$ for $7 \mathrm{~d}$ (Suprapure, ROMIL, UK), rinsed three times with ultrapure water (UPW, ELGA, UK), stored in $\mathrm{HNO}_{3} 2 \%$ for $7 \mathrm{~d}$ (Suprapure, ROMIL, UK), rinsed three times with UPW and then stored in $\mathrm{HNO}_{3} 1 \%$ (Ultrapure, ROMIL, UK) until the day before the sample collection, when they were rinsed three times with UPW and dried overnight under a laminar flow hood (Class 100). The samples were kept frozen and shipped to Italy for analysis. Once melted, the samples were acidified to $\mathrm{pH} 1$ using $\mathrm{HNO}_{3}$ (Suprapure, ROMIL, UK). To ensure an effective dissolution of Fe particles, samples were stored at room temperature and analyzed $30 \mathrm{~d}$ after the acidification without any additional filtration step. We adopted this approach because analysis immediately after the acidification step might have led to uncertainties attributable to the Fe dissolution kinetics (Edwards, 1999; Koffman et al., 2014). Our choice was consistent with other studies that have indicated that samples to be used for the calculation of atmospheric fluxes must be acidified for at least 1 month prior to analysis in order to avoid any possible misinterpretation of the trace element data (Koffman et al., 2014). We will refer to this fraction as total dissolvable Fe (TDFe); total dissolvable Fe includes both the most labile fraction (dissolved iron, $\mathrm{DFe}$ ), which is rendered soluble under mildly acidic conditions (Hiscock et al., 2013), and the fraction enclosed in ironbearing mineral particles. TDFe does not directly represent the actual bioavailable $\mathrm{Fe}$ that can be dissolved into seawater at $\mathrm{pH} 8$, but, considering that TDFe and $\mathrm{DFe}$ are significantly correlated (Du et al., 2020; Xiao et al., 2020), it represents an upper limit of the eolian Fe potentially available for the phytoplankton (Edwards et al., 2006).

\subsection{Analytical procedure and performances}

The ice samples were analyzed with an Inductively Coupled Plasma Single Quadrupole Mass Spectrometer (ICPqMS, Agilent 7500 series, USA) equipped with a quartz Scott spray chamber for the determination of $\mathrm{Ca}, \mathrm{Na}$ and $\mathrm{Fe}$. To minimize any kind of contamination, all of the instrument tubes were flushed before the analysis for $2 \mathrm{~h}$ with $2 \% \mathrm{HNO}_{3}$ (Suprapure, ROMIL, UK). A 120 s rinsing step with $2 \% \mathrm{HNO}_{3}$ (Suprapure, ROMIL, UK) occurred after each sample analysis to reduce any possible memory effect. The vials used for the standard preparation were cleaned following the same procedure adopted for the ice samples. Considering the isobaric and polyatomic interferences affecting $\mathrm{Fe}$, this element was quantified using the interference-free isotope ${ }^{57} \mathrm{Fe}$. External calibration curves with acidified standards $\left(2 \% \mathrm{HNO}_{3}\right.$, Suprapure, ROMIL, UK) were prepared for $\mathrm{Ca}, \mathrm{Na}$ and $\mathrm{Fe}$ from the dilution of a certified singleelement $1000 \mathrm{ppm} \pm 1 \%$ standard solution (Fisher Chemical, USA). The resulting $R^{2}$ for the external calibration curves was 0.999 for all of the elements. The limit of detection (LoD) for ${ }^{57} \mathrm{Fe}$, calculated as 3 times the standard deviation of the blank, was $0.8 \mu \mathrm{g} \mathrm{L}^{-1}$. To assess accuracy for Fe, the TM-RAIN04 certified reference material (National Research Council of Canada) was measured every 50 samples. The accuracy was determined as a recovery percentage calculated as $O / T \%$, where $O$ is the determined value, and $T$ is the certified value. For Fe, the accuracy was $104 \%$, whereas precision, calculated as relative standard deviation (RSD \%) of selected samples read multiple times $(n=5)$ during the analysis, was on average $5 \%$ (7\% for samples $(n=3)$ from the interglacial period, and $4 \%$ for samples $(n=3)$ from the last glacial period). For $\mathrm{Ca}$ and $\mathrm{Na}$, the $\mathrm{LoD}$ was 1 and $3 \mu \mathrm{gL}^{-1}$, respectively. In the absence of a certified reference material, $\mathrm{Ca}$ and $\mathrm{Na}$ accuracy was calculated using a quality control (QC) sample prepared at $10 \mu \mathrm{g} \mathrm{L}^{-1}$ and measured every 50 samples. Accuracy for $\mathrm{Ca}$ and $\mathrm{Na}$, calculated as described above, was $94 \%$ and $108 \%$, respectively, whereas precision (RSD \%) was on average 6\% (4\% for samples from the interglacial period, and $7 \%$ for samples from the last glacial period) and $2 \%$ (for both periods), respectively.

The non-sea-salt $\mathrm{Ca}$ concentration is commonly used as proxy for terrestrial inputs in polar regions, and it is calculated as $\mathrm{nssCa}=[\mathrm{Ca}]-([\mathrm{Ca}] /[\mathrm{Na}])_{\mathrm{sw}} \cdot[\mathrm{Na}]$, where "sw" indicates seawater. 


\section{Results and discussion}

\subsection{Fe fluxes from the NEEM core}

$\mathrm{Fe}$ and nssCa concentrations and fluxes were calculated as $F=C \cdot A$, where $F$ is the $\mathrm{Fe}$ flux (in $\mathrm{mg} \mathrm{m}^{-2} \mathrm{yr}^{-1}$ ), $C$ is the $\mathrm{Fe}$ or nssCa concentration (in $\mathrm{ng} \mathrm{g}^{-1}$ ) and $A$ the accumulation (in $\mathrm{m} \mathrm{yr}^{-1}$ ice equivalent) previously determined by Rasmussen et al. (2013). A pattern of higher dust (expressed as $\mathrm{nssCa}^{2+}$ ) and $\mathrm{Fe}$ fluxes during colder climate periods and lower dust and $\mathrm{Fe}$ fluxes during warmer climate periods is clearly recognizable (Fig. 2, Table 2).

The Holocene $(0.042-11.7 \mathrm{ka})$ was characterized by average $\mathrm{Fe}$ fluxes of $0.5 \mathrm{mg} \mathrm{m}^{-2} \mathrm{yr}^{-1}$ that varied between 0.01 and $5.3 \mathrm{mg} \mathrm{m}^{-2} \mathrm{yr}^{-1}$ (Fig. 2). The coefficient of variability (CV), calculated as the ratio between the standard deviation and the mean value, was 1.2. The more recent 4000 years are characterized by the highest average Fe fluxes $\left(0.6 \pm 0.4 \mathrm{mg} \mathrm{m}^{-2} \mathrm{yr}^{-1}\right)$. The lowest Fe fluxes were recorded between 4000 and 8000 years b2k $\left(0.3 \pm 0.2 \mathrm{mg} \mathrm{m}^{-2} \mathrm{yr}^{-1}\right)$. During the Younger Dryas (YD; 11.7-12.9 ka), an abrupt cooling was observed with a drop in the $\delta^{18} \mathrm{O}$ value from $-36.9 \%$ o to $-43.1 \%$. Coincidently, the recorded average $\mathrm{Fe}$ fluxes rose to $1.2 \pm 0.4 \mathrm{mg} \mathrm{m}^{-2} \mathrm{yr}^{-1}$, higher than both the $12.9-13.9 \mathrm{ka}\left(0.5 \pm 0.3 \mathrm{mg} \mathrm{m}^{-2} \mathrm{yr}^{-1}\right)$ and the $10.7-11.7 \mathrm{ka}$ $\left(0.3 \pm 0.2 \mathrm{mg} \mathrm{m}^{-2} \mathrm{yr}^{-1}\right)$ periods.

The last glacial period (11.7-108 ka) showed Fe fluxes 4 times higher $\left(2.0 \pm 2.2 \mathrm{mg} \mathrm{m}^{-2} \mathrm{yr}^{-1}\right)$ than the Holocene, spanning from 0.05 to $16.5 \mathrm{mg} \mathrm{m}^{-2} \mathrm{yr}^{-1}$ (Fig. 2). However, a significant variability during the last glacial period was detected. During the LGM and MIS 4, average Fe fluxes were 7 times $\left(3.6 \pm 2.3 \mathrm{mg} \mathrm{m}^{-2} \mathrm{yr}^{-1}\right)$ and 10 times $\left(5.8 \pm 2.8 \mathrm{mg} \mathrm{m}^{-2} \mathrm{yr}^{-1}\right)$ greater than the Holocene average. $\mathrm{Fe}$ fluxes also increased during the MIS 5c-MIS5b transition (87 ka), when a concurrent decrease in $\delta^{18} \mathrm{O}$ values was observed. During MIS 5c and MIS 5d, Fe fluxes were comparable with those detected during the Holocene. The high frequency of the Dansgaard-Oeschger (D-O) events during MIS 3 was mirrored by the high variability in both nssCa and $\mathrm{Fe}$ fluxes. Each stadial period corresponded to an increase in both $\mathrm{Fe}$ and nssCa. However, their variability was significantly different. During MIS 3, Fe fluxes showed maximum values greater than $5 \mathrm{mg} \mathrm{m}^{-2} \mathrm{yr}^{-1}$ during D-O 4, 9, 12 and $15\left(8.5,6.5,7.5\right.$ and $6.6 \mathrm{mg} \mathrm{m}^{-2} \mathrm{yr}^{-1}$ respectively), and lower than $5 \mathrm{mg} \mathrm{m}^{-2} \mathrm{yr}^{-1}$ during D-O 6, 7, 8, 10, 11 and $13\left(3.9,2.6,4.1,2.6,2.7\right.$ and $3.2 \mathrm{mg} \mathrm{m}^{-2} \mathrm{yr}^{-1}$ respectively). This variability was significantly higher than that recorded for $\mathrm{nssCa}$, which showed maximum values close to $20 \mathrm{mg} \mathrm{m}^{-2} \mathrm{yr}^{-1}$ for all of the $\mathrm{D}-\mathrm{O}$ events.

\subsection{Comparison with Fe fluxes from Antarctic ice cores}

The NEEM Fe ice core record allows for the first comparison of Fe concentrations and fluxes between the Arctic and Antarctica (Fig. 3, Table 3). The only Antarctic Fe records that can reach at least the LGM are from Talos Dome (TD) (Spolaor et al., 2013; Vallelonga et al., 2013), Law Dome (LD) (Edwards et al., 2006; Edwards et al., 1998) and EPICA Dome C (EDC) (Wolff et al., 2006). However, we point out that both the samples from Dome $\mathrm{C}$ and Talos Dome were acidified for at least $24 \mathrm{~h}$, leading to a possible underestimation of the actual TDFe concentration. This implies that the general trends and features can be comparable with the NEEM record, whereas absolute concentrations might differ due to the different acidification procedure used (Koffman et al., 2014).

In Antarctica, the average Fe flux and concentration values varied significantly among the different sites during the Holocene with similar values recorded at the coastal sites (TD) and lower values recorded in the internal Antarctic Plateau (EDC) (Table 3). For TD, this was explained both through changes in atmospheric transport patterns across Antarctica and through an additional local input of dust from proximal Antarctic ice-free zones that affected coastal sites more than the central plateau, which was exclusively exposed to remote sources such as southern South America (Albani et al., 2012; Delmonte et al., 2010b; Vallelonga et al., 2013).

During the LGM, both TD and EDC shared a similar dust flux loading, comprised between 10 and $15 \mathrm{mg} \mathrm{m}^{-2} \mathrm{yr}^{-1}$ (Baccolo et al., 2018), and the same dust source region, as confirmed by the $\mathrm{Sr}-\mathrm{Nd}$ isotopes (Delmonte et al., 2010a). Compared with the Holocene, the atmospheric dust fluxes in TD increased by a factor 6 , whereas the increase was by approximately a factor 25 in EDC (Delmonte et al., 2010b). This is mirrored by a similar average Fe flux enhancement compared to the Holocene with values that were up to 4 - and 21-fold higher, respectively (Vallelonga et al., 2013; Wolff et al., 2006). These discrepancies between the two sites are likely due to the higher Holocene dust flux observed in TD compared with EDC, as a consequence of a relevant local dust contribution at TD (Baccolo et al., 2018; Delmonte et al., 2010b).

During the last glacial period, the most relevant dust source was southern South America for both TD and EDC (Basile et al., 1997; Delmonte et al., 2010b; Lambert et al., 2008). Dust fluxes peaked during MIS 4 where both sites recorded maximum values around $10 \mathrm{mg} \mathrm{m}^{-2} \mathrm{yr}^{-1}$ (Lambert et al., 2008; Vallelonga et al., 2013) and comparable Fe fluxes $\left(0.17 \pm 0.07 \mathrm{mg} \mathrm{m}^{-2} \mathrm{yr}^{-1}\right.$ at $\mathrm{TD}$ and $0.12 \pm 0.07 \mathrm{mg} \mathrm{m}^{-2} \mathrm{yr}^{-1}$ at EDC) (Vallelonga et al., 2013; Wolff et al., 2006).

The LD record, due to the different analytical preparation of the samples, is not directly comparable with TD and EDC. Nevertheless, we can still evaluate and discuss the Fe flux ratio between the Holocene and the LGM. Unfortunately, for the LD record, there is no dust profile available, meaning that it is not possible to define the main dust and Fe sources for this location, although the Australian continent has been an important source of mineral dust in the recent past (Edwards et al., 2006; Vallelonga et al., 2002). During the LGM, 

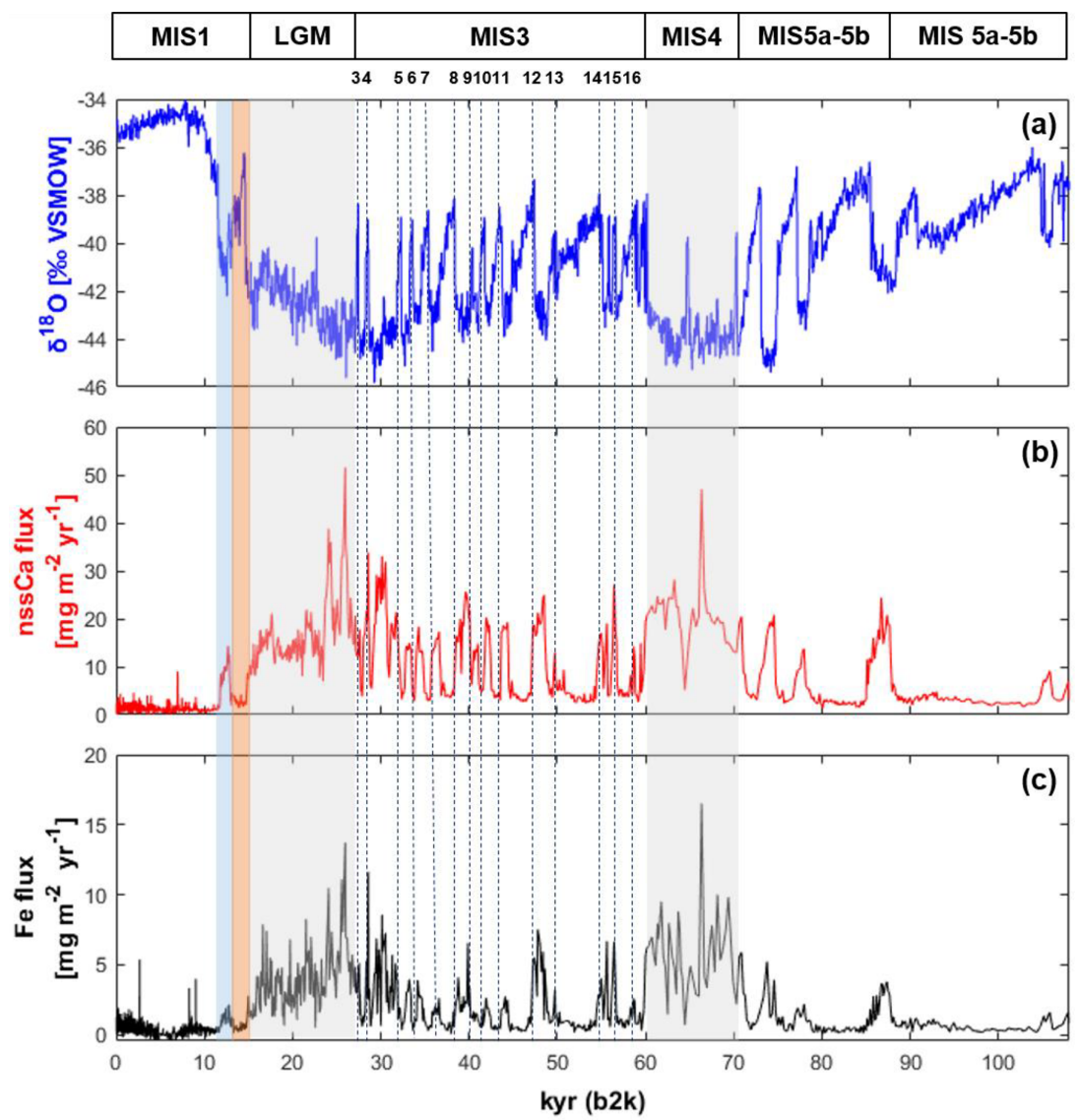

Figure 2. (a) The $\delta^{18} \mathrm{O}$ (blue line) profile from the NGRIP ice core (North Greenland Ice Core Project Members, 2007). (b) The nssCa flux (red line) from the NEEM ice core, and (c) the Fe flux (black line) from the NEEM ice core. The shaded blue rectangle denotes the Younger Dryas, and the shaded orange rectangle denotes the Bølling-Allerød. The numbers above panel (a) indicate the Dansgaard-Oeschger events from 3 to 16.

Table 2. Fe and nssCa average concentrations $\left(\mathrm{ng} \mathrm{g}^{-1}\right)$ and fluxes $\left(\mathrm{mg} \mathrm{m}^{-2} \mathrm{yr}^{-1}\right)$ from the NEEM ice core. More details are given in the text. The coefficient of variability (CV) was calculated for Fe and nssCa fluxes and is reported in bold.

\begin{tabular}{|c|c|c|c|c|}
\hline & $\begin{array}{r}\text { Fe average } \\
\text { concentration } \\
\left(\mathrm{ng} \mathrm{g}^{-1}\right)\end{array}$ & $\begin{array}{r}\text { Fe average } \\
\text { fluxes } \\
\left(\mathrm{mg} \mathrm{m}^{-2} \mathrm{yr}^{-1}\right)\end{array}$ & $\begin{array}{r}\text { nssCa average } \\
\text { concentration } \\
\left(\mathrm{ng} \mathrm{g}^{-1}\right)\end{array}$ & $\begin{array}{r}\text { nssCa average } \\
\text { fluxes } \\
\left(\mathrm{mg} \mathrm{m}^{-2} \mathrm{yr}^{-1}\right)\end{array}$ \\
\hline Holocene $(0.042-11.7 \mathrm{ka})$ & 2.9 & $0.5(\mathrm{CV} 1.2)$ & 7.2 & $1.4($ CV 2.3) \\
\hline Glacial (11.7-108 ka) & 44.3 & $2.0($ CV 1.1) & 210.8 & $10.0($ CV 0.8) \\
\hline Younger Dryas (11.7-12.9 ka) & 18.2 & $1.2(\mathrm{CV}$ 0.3) & 135.2 & $8.5($ CV 0.4) \\
\hline LGM (14.5-26.5 ka) & 86.3 & $3.6(\mathrm{CV}$ 0.6) & 273.3 & 12.3 (CV 0.7) \\
\hline MIS $3(26.5-60 \mathrm{ka})$ & 45.5 & $1.9($ CV 1.0) & 216.6 & $10.2(\mathrm{CV}$ 0.8) \\
\hline MIS 4 (60-71 ka) & 146.4 & $5.8(\mathbf{C V}$ 0.5) & 510.2 & 20.5 (CV 0.3) \\
\hline MIS 5a-MIS 5b (71-87 ka) & 17.0 & $1.1(\mathrm{CV} 1.0)$ & 98.6 & $6.3(\mathrm{CV} 0.8)$ \\
\hline MIS 5c-MIS 5d (87-108 ka) & 6.5 & 0.8 (CV 0.8) & 50.4 & 4.3 (CV 0.9) \\
\hline
\end{tabular}

Fe fluxes increased 10-fold compared with the Holocene period, 2.5 times more than what was observed in TD. Similarly to what was observed in the EDC record, this difference might be explained by the absence of local dust sources that affected LD during the Holocene or by the lower sam- pling frequency for the LD record $(n=27)$ compared with $\mathrm{TD}(n=801)$.

Despite the different acidification times, the overall picture during the Holocene is that the average Fe fluxes in NEEM $\left(0.5 \mathrm{mg} \mathrm{m}^{-2} \mathrm{yr}^{-1}, \mathrm{CV}=1.2\right)$ were higher than in Antarc- 

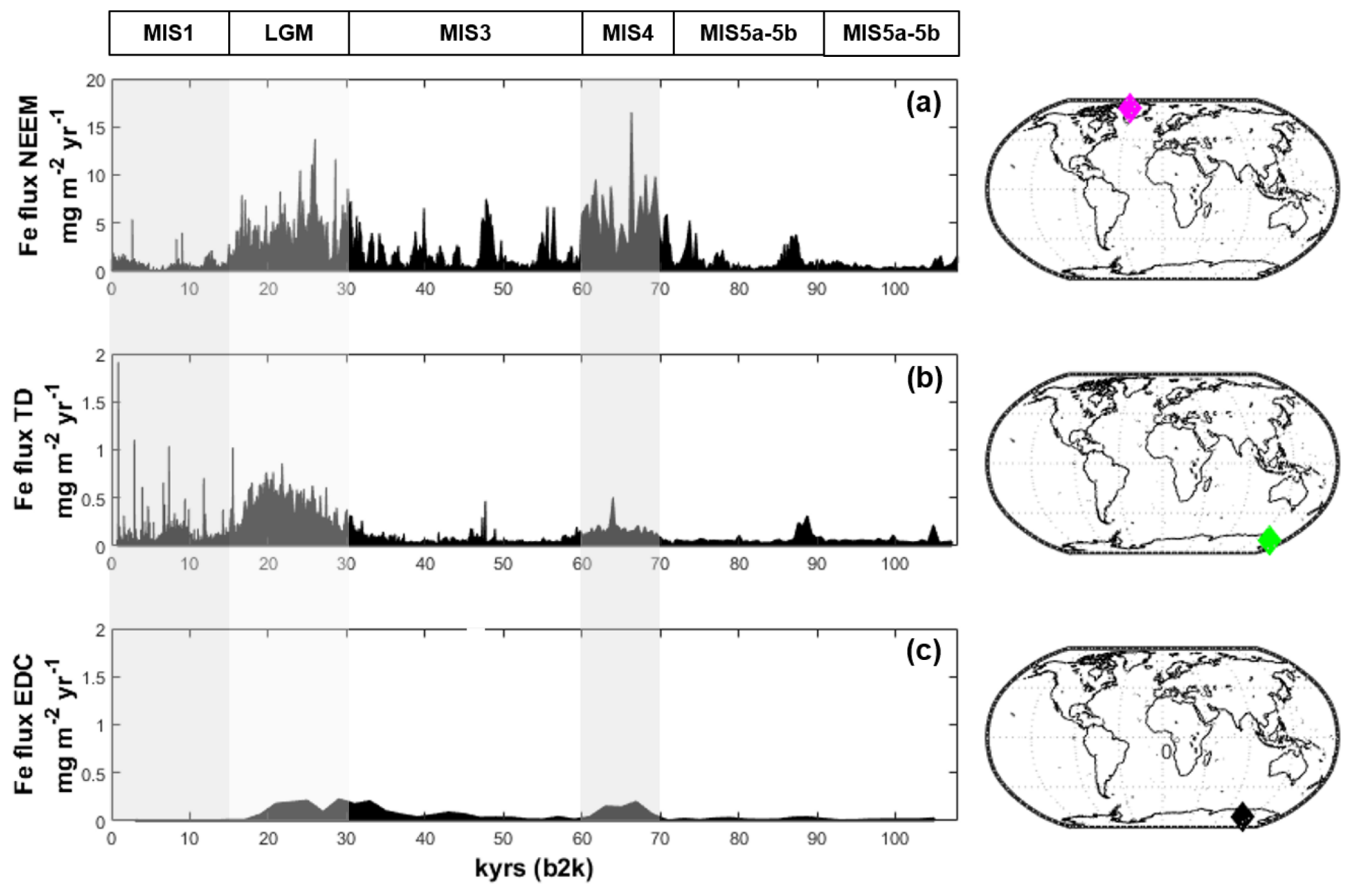

Figure 3. Comparison of the Fe fluxes among (a) NEEM (pink diamond; this work), (b) TD (green diamond; Vallelonga et al., 2013) and (c) EDC (black diamond; Wolff et al., 2006). Note that the $y$ axis for NEEM ranges from 0 to $20 \mathrm{mg} \mathrm{m}^{-2} \mathrm{yr}^{-1}$, whereas the $y$ axis for TD and EDC ranges from 0 to $2 \mathrm{mg} \mathrm{m}^{-2} \mathrm{yr}^{-1}$.

Table 3. Comparison of the average Fe concentration ([Fe], in $\mathrm{ng} \mathrm{g}^{-1}$ ) and fluxes (in $\mathrm{mg} \mathrm{m}^{-2} \mathrm{yr}^{-1}$ ) among four different ice cores: NEEM, Talos Dome (Vallelonga et al., 2013), Law Dome (Edwards et al., 2006) and Dome C (Wolff et al., 2006). NA stands for not available. The average Fe concentration at DC is not available, as the accumulation rate at that site during MIS4 is unavailable. Data from Law Dome span from 59 to $8.5 \mathrm{ka}$ (for the Holocene) and from 18.2 to $23.7 \mathrm{ka}$ (for the LGM). The coefficient of variability (CV) was calculated for Fe fluxes and is reported in bold for all of the cores.

\begin{tabular}{|c|c|c|c|c|c|c|c|c|}
\hline & \multirow{2}{*}{\multicolumn{2}{|c|}{$\begin{array}{c}\text { Greenland } \\
\text { NEEM }\end{array}$}} & \multicolumn{6}{|c|}{ Antarctica } \\
\hline & & & \multicolumn{2}{|c|}{ Talos Dome } & \multicolumn{2}{|c|}{ Law Dome } & \multicolumn{2}{|c|}{ Dome C } \\
\hline & $\begin{array}{r}{[\mathrm{Fe}]} \\
\left(\mathrm{ng} \mathrm{g}^{-1}\right)\end{array}$ & $\begin{array}{r}\mathrm{Fe} \text { flux } \\
\left(\mathrm{mg} \mathrm{m}^{-2} \mathrm{yr}^{-1}\right)\end{array}$ & $\begin{array}{r}{[\mathrm{Fe}]} \\
\left(\mathrm{ng} \mathrm{g}^{-1}\right)\end{array}$ & $\begin{array}{r}\text { Fe flux } \\
\left(\mathrm{mg} \mathrm{m}^{-2} \mathrm{yr}^{-1}\right)\end{array}$ & $\begin{array}{r}{[\mathrm{Fe}]} \\
\left(\mathrm{ng} \mathrm{g}^{-1}\right)\end{array}$ & $\begin{array}{r}\text { Fe flux } \\
\left(\mathrm{mg} \mathrm{m}^{-2} \mathrm{yr}^{-1}\right)\end{array}$ & $\begin{array}{r}{[\mathrm{Fe}]} \\
\left(\mathrm{ng} \mathrm{g}^{-1}\right)\end{array}$ & $\begin{array}{r}\mathrm{Fe} \text { flux } \\
\left(\mathrm{mg} \mathrm{m}^{-2} \mathrm{yr}^{-1}\right)\end{array}$ \\
\hline Holocene $(0.042-11.7 \mathrm{ka})$ & 2.9 & 0.5 (CV 1.2) & 1.4 & 0.09 (CV 1.2) & 0.09 & 0.04 (CV 0.5) & 0.2 & 0.007 (CV 0.2) \\
\hline LGM (14.5-26.5 ka) & 86.3 & $3.6(\mathrm{CV}$ 0.6) & 10.3 & 0.4 (CV 0.5) & 2.4 & $0.4(\mathbf{C V} 0.7)$ & 16 & 0.15 (CV 0.5) \\
\hline MIS4 (60-71 ka) & 146.4 & $5.8($ CV 0.5) & 3.1 & 0.17 (CV 0.4) & NA & NA & NA & 0.12 (CV 0.6) \\
\hline LGM / Holocene ratio & 30 & 7 & 7 & 4 & 27 & 10 & 80 & 21 \\
\hline MIS4 / LGM ratio & 1.7 & 1.5 & 0.3 & 0.4 & NA & NA & NA & 0.8 \\
\hline
\end{tabular}

tica. Among the Antarctic Fe fluxes, TD $\left(0.09 \mathrm{mg} \mathrm{m}^{-2} \mathrm{yr}^{-1}\right.$, $\mathrm{CV}=1.2)$ and $\mathrm{LD}\left(0.04 \mathrm{mg} \mathrm{m}^{-2} \mathrm{yr}^{-1}, \mathrm{CV}=0.5\right)$ were higher than those recorded at EDC $\left(0.007 \mathrm{mg} \mathrm{m}^{-2} \mathrm{yr}^{-1}\right.$, $\mathrm{CV}=0.2)$.

In NEEM, the LGM (19-26.5 ka) was characterized by a 10-fold and 7-fold enhancement in dust (expressed as nssCa) and Fe fluxes, respectively. A similar behavior was observed in the Antarctic cores as described above (Table 3). Considering that the atmospheric $\mathrm{CO}_{2}$ concentration dropped down to $180 \mathrm{ppm}$ (Köhler et al., 2017), the global Fe flux enhancement likely contributed to part of this decrease, promoting marine productivity in some HNLC regions (Amo and Mi- nagawa, 2003; Kawahata et al., 2000; Martínez-Garcia et al., 2011).

During MIS 4 (60-71 ka), NEEM Fe fluxes were higher than all of the other investigated records. Compared with the LGM average, dust (Ruth, 2007), nssCa and $\mathrm{Fe}$ fluxes (this work) in the Arctic during MIS 4 exhibited a $\approx 1.5$-fold increase (Table 3), while they were lower both in TD and EDC. To explain this behavior we advance some hypotheses. The first is that the increase in dust and Fe fluxes can be attributable to changes in the atmospheric circulation, likely due to the topographic influence of the Laurentide Ice Sheet (LIS). Indeed, during the LGM, the LIS was nearly 2 times 
larger than at MIS 4 (Löfverström et al., 2014; Tulenko et al., 2020), and it might have caused a stronger meridional splitting of the westerlies (Löfverström et al., 2014) and a southward migration of their mean position (Kang et al., 2015; Manabe and Broccoli, 1985). The southward shift during the LGM might have produced a reduction in strong winds passing over the source areas (i.e., Taklimakan and Gobi deserts) (Kang et al., 2015) and/or a stronger southward Fe and dust deposition over the Chinese Loess Plateau (Zhang et al., 2014) and the midlatitude North Pacific (Sun et al., 2018). In contrast, during MIS 4, the westerlies might have been located northward (i.e., over the Taklimakan and Gobi deserts) and characterized by a less marked meridional splitting (Löfverström et al., 2014), conveying a larger amount of dust to Greenland. We also propose two alternative hypotheses that rely on (1) the possibility that additional dust sources (e.g., Saharan dust) might have reached Greenland during MIS 4 and on the fact that (2) during MIS 4, the Asian monsoon system was stronger in winter than in summer, producing drier conditions that caused an enhanced dust production and transport to Greenland (Xiao et al., 1999). However, to better address this point, a more comprehensive investigation that involves a large set of paleorecords and atmospheric modeling is required, although this is beyond the scope of this paper.

\subsection{Comparison with lower-resolution Fe NEEM measurements}

A parallel study that reported the Fe concentration from the NEEM ice core was recently published (Xiao et al., 2020). It reports the TDFe and DFe concentrations and fluxes with a lower temporal resolution $(n=166)$ than the current investigation $(n=1596)$. Moreover, the analytical approach was different, as the melted ice samples were filtered at $0.45 \mu \mathrm{m}$ and acidified for 6 weeks before the analysis. Even though the overall pattern between the two records is similar, we observe several differences between Xiao et al. (2020) and our study: (a) the average Fe concentration over the entire record is 4-fold higher than that found in our investigation (101.4 $\mathrm{ng} \mathrm{g}^{-1}$ vs. $20.4 \mathrm{ng} \mathrm{g}^{-1}$ ); (b) the Fe concentration range is wider $\left(1.5-1194.5 \mathrm{ng} \mathrm{g}^{-1}\right.$ vs. $>\mathrm{LoD}-$ $457.6 \mathrm{ng} \mathrm{g}^{-1}$ ) compared with the data presented in this paper; (c) average Fe fluxes are 2.4-fold higher during the Holocene $\left(1.2 \mathrm{mg} \mathrm{m}^{-2} \mathrm{yr}^{-1}\right.$ vs. $\left.0.5 \mathrm{mg} \mathrm{m}^{-2} \mathrm{yr}^{-1}\right)$ and 3.5 -fold higher during the LGM $\left(12.5 \mathrm{mg} \mathrm{m}^{-2} \mathrm{yr}^{-1}\right.$ vs. $\left.3.6 \mathrm{mg} \mathrm{m}^{-2} \mathrm{yr}^{-1}\right)$ compared with those recorded in this study; (d) the LGM Fe flux showed a 10-fold increase during the Holocene, compared with the 7-fold enhancement that we observed; (e) the TDFe fluxes and concentrations were higher during the LGM than during MIS 4, whereas we found higher fluxes during MIS 4, consistent with a similar enhancement of nssCa and dust (Ruth, 2007).

Possible reasons for these differences might stem from the different temporal resolution and the discrepancies between the adopted analytical approaches; this highlights the need to standardize the analytical procedures when trace elements are analyzed in ice and snow samples in order to have a more reliable comparison among both different and identical locations.

\subsection{Fe and marine productivity in the Northern Hemisphere}

Considering the biological relevance of $\mathrm{Fe}$ and taking advantage of the Fe flux record retrieved from the NEEM ice core, one important question remains regarding whether its flux increase during the last glacial period triggered the marine productivity in the HNLC region of the North Pacific (Olgun et al., 2011).

Nowadays, a significant amount of Asian dust $\left(250 \mathrm{Mt} \mathrm{yr}^{-1}\right)$ is primarily deposited over the HNLC region of the subarctic Pacific (Serno et al., 2014; Zhang et al., 2003), and the marine productivity changes in this oceanic region might reflect potential $\mathrm{Fe}$ fertilization effects promoted by atmospheric Fe supply. During modern times, both increases in the eolian influx from Asia (Young et al., 1991) and sporadic Fe input from volcanic eruptions (Langmann et al., 2010) have resulted in an enhancement of MPP by more than $60 \%$. Moreover, recent Fe fertilization experiments performed south of the Gulf of Alaska (McDonald et al., 1999; Tsuda et al., 2003) have shown significant increases in the abundance of diatoms and in the chlorophyll- $a$ concentration (Boyd et al., 1996), indicating that the North Pacific is possibly sensitive to atmospheric $\mathrm{Fe}$ inputs. However, no data are available to evaluate if the $\mathrm{Fe}$ sensitivity of the subarctic Pacific Ocean holds over even longer timescales or if an increase in the eolian Fe supply, observed during glacial periods, could explain the MPP variability in the subarctic Pacific Ocean. To address these points, we compared the NEEM Fe record with different marine sediment cores (Table 4).

For both interglacial and glacial periods, previous geochemical evidence indicates that the dust source influencing Greenland and the North Pacific mainly originated from the East Asian deserts (Schüpbach et al., 2018; Serno et al., 2014). However, considering that there are no eolian Fe flux records from the marine sediment cores, they might have received different amount of Fe compared with what is observed in the ice core record. Through a comparison between a marine sediment record from the western subarctic Pacific Ocean (SO202-07-6) and the NGRIP ice core, it has been shown that dust fluxes changed coherently and simultaneously during abrupt climate changes, although the amplitude of the change was different (Serno et al., 2015). The larger variability observed in NGRIP, as well as in NEEM, compared with marine sediments indicates changes in the atmospheric dust transport from the source areas to Greenland (e.g., rate of aerosol rainout and different wind strength). 
Table 4. Summary of locations and data sources for all the cores (both ice and sediment cores) discussed in the text. (NH stands for Northern Hemisphere, and SH stands for Southern Hemisphere.)

\begin{tabular}{lllll}
\hline Name & Core & Location & Reference & Coordinates (lat, long) \\
\hline NEEM ice & Ice core & $\mathrm{NH}$ & This work & $77^{\circ} 45^{\prime} \mathrm{N}, 51^{\circ} 06^{\prime} \mathrm{W}$ \\
Talos Dome & Ice core & SH & Vallelonga et al. (2013) & $73^{\circ} 0^{\prime} \mathrm{S}, 158^{\circ} 0^{\prime} \mathrm{E}$ \\
Law Dome & Ice core & SH & Edwards et al. (2006) & $66^{\circ} 46^{\prime} \mathrm{S}, 112^{\circ} 48^{\prime} \mathrm{E}$ \\
Dome C & Ice core & SH & Wolff et al. (2006) & $75^{\circ} 06^{\prime} \mathrm{S}, 123^{\circ} 23^{\prime} \mathrm{E}$ \\
ODP882 & Marine sediment & $\mathrm{NH}$ & Haug et al. (1995) & $50^{\circ} 22^{\prime} \mathrm{N}, 167^{\circ} 36^{\prime} \mathrm{E}$ \\
ODP887 & Marine sediment & $\mathrm{NH}$ & McDonald et al. (1999) & $54^{\circ} 22^{\prime} \mathrm{N}, 148^{\circ} 27^{\prime} \mathrm{W}$ \\
SO202-27-6 & Marine sediment & $\mathrm{NH}$ & Meheust et al. (2018) & $54^{\circ} 12^{\prime} \mathrm{N}, 149^{\circ} 36^{\prime} \mathrm{W}$ \\
SO202-07-6 & Marine sediment & $\mathrm{NH}$ & Meheust et al. (2018) & $51^{\circ} 16^{\prime} \mathrm{N}, 167^{\circ} 42^{\prime} \mathrm{E}$ \\
S-2 & Marine sediment & $\mathrm{NH}$ & Amo and Minagawa (2003) & $33^{\circ} 22^{\prime} \mathrm{N}, 159^{\circ} 08^{\prime} \mathrm{E}$ \\
\hline
\end{tabular}

Recently, it has been proposed that additional dust sources might have influenced Greenland in the last $31 \mathrm{kyr}$ (Han et al., 2018; Lupker et al., 2010). Strontium and lead isotopes indicate that Saharan dust contributed to the overall NEEM dust budget during the Younger Dryas $(12 \%-73 \%)$ and between 17 and $22 \mathrm{ka}(16 \%-70 \%)$, while the Taklimakan and Gobi contribution (i.e., eastern Asia sources) was dominant (55\%-94\%) prior to $22 \mathrm{ka}$ (Han et al., 2018). However, despite the Saharan dust source, we assume that the main dust source for the NEEM ice core during the last glacial period is represented by the Gobi and Taklimakan deserts (Svensson et al., 2000). This is coherent with the dust changes' synchronicity among Greenland, the Chinese loess (Ruth et al., 2007) and the northern Pacific sediment records located downwind of the Asian dust sources (Schüpbach et al., 2018; Serno et al., 2015). Nevertheless, additional investigations to assess the magnitude of the Saharan dust contribution prior to $31 \mathrm{ka}$ and to identify other possible source regions are needed.

All variables considered (i.e., different dust amplitude and other potential dust sources), and observing that the overall pattern of higher dust deposition during the coldest periods is consistent between the ice and sediment core records, we assumed that the Fe flux changes observed in NEEM are representative for the eolian Fe supply to the subarctic Pacific Ocean.

To evaluate whether past marine productivity was influenced by the atmospheric $\mathrm{Fe}$ supply for the period ranging from the LGM to the Holocene, we compared the NEEM record with the high temporal resolution SO20227-6 (from the Patton-Murray Rise plateau, eastern subarctic Pacific Ocean) and the SO202-07-6 (from the Detroit Seamount, western subarctic Pacific Ocean) productivity records (Méheust et al., 2018). For a long-term record, we relied on the ODP887 (McDonald et al., 1999) and the ODP882 (Haug et al., 1995) sediment cores, located close to SO202-27-6 and SO202-07-6, respectively. A comparison over the last $108 \mathrm{kyr}$ between the NEEM record and the S2 sediment core (from the Shatsky Rise, midlatitude North
Pacific) was also performed (Amo and Minagawa, 2003) (Fig. 4, Table 4).

The past marine primary productivity reconstruction was performed relying on the $\mathrm{Si} / \mathrm{Al}$ ratio, the percentage of biogenic silica and the brassicasterol concentration. The $\mathrm{Si} / \mathrm{Al}$ ratio is used as a proxy for opal, or biogenic silica (diatoms), in the absence of directly measured opal concentrations. The normalization to $\mathrm{Al}$ removes any possible variable inputs of lithogenic detritus (McDonald et al., 1999). Brassicasterol is a sterol compound that has been used as a molecular indicator of the presence of diatoms (Sachs and Anderson, 2005). The brassicasterol concentration is also used, along with highly branched isoprenoid alkenes $\left(\mathrm{IP}_{25}\right)$, for the phytoplankton $\mathrm{IP}_{25}$ index $\left(\mathrm{PIP}_{25}\right)$ calculation, which is a proxy for the evaluation of past sea ice conditions (Méheust et al., 2018; Müller et al., 2011)

\subsubsection{From the LGM to the Holocene}

During the Last Glacial Maximum, the Fe fluxes recorded in the NEEM ice core were 7 times higher than during the Holocene. However, marine productivity in the subarctic $\mathrm{Pa}-$ cific Ocean, expressed as the $\mathrm{Si} / \mathrm{Al}$ ratio (McDonald et al., 1999), the percentage of biogenic silica (Haug et al., 1995) and the brassicasterol concentration (Méheust et al., 2018), was at its lowest level (Figs. 4, 5). Reconstructions based on the foraminifera-bound $\delta^{15} \mathrm{~N}\left(\mathrm{FB}-\delta^{15} \mathrm{~N}\right)$, a proxy which indicates the degree of nitrate consumption by phytoplankton (Martínez-García et al., 2014), showed that, in the western subarctic Pacific Ocean, the nitrate consumption was more complete during the LGM and the YD (i.e., when MPP was low) compared with the warmest periods (Ren et al., 2015). In other words, during the coldest and dustiest periods, the nitrate consumption efficiency was higher (i.e., increase in the FB- $\delta{ }^{15} \mathrm{~N}$ values) than during the interglacials, even though MPP was low. This apparent contradiction can be explained by an increase in water stratification (either by reduced upwelling or vertical mixing), where the most nutrient-rich and oxygen-depleted waters were shifted to deeper depths, whereas nutrient-depleted and better-ventilated waters rested 

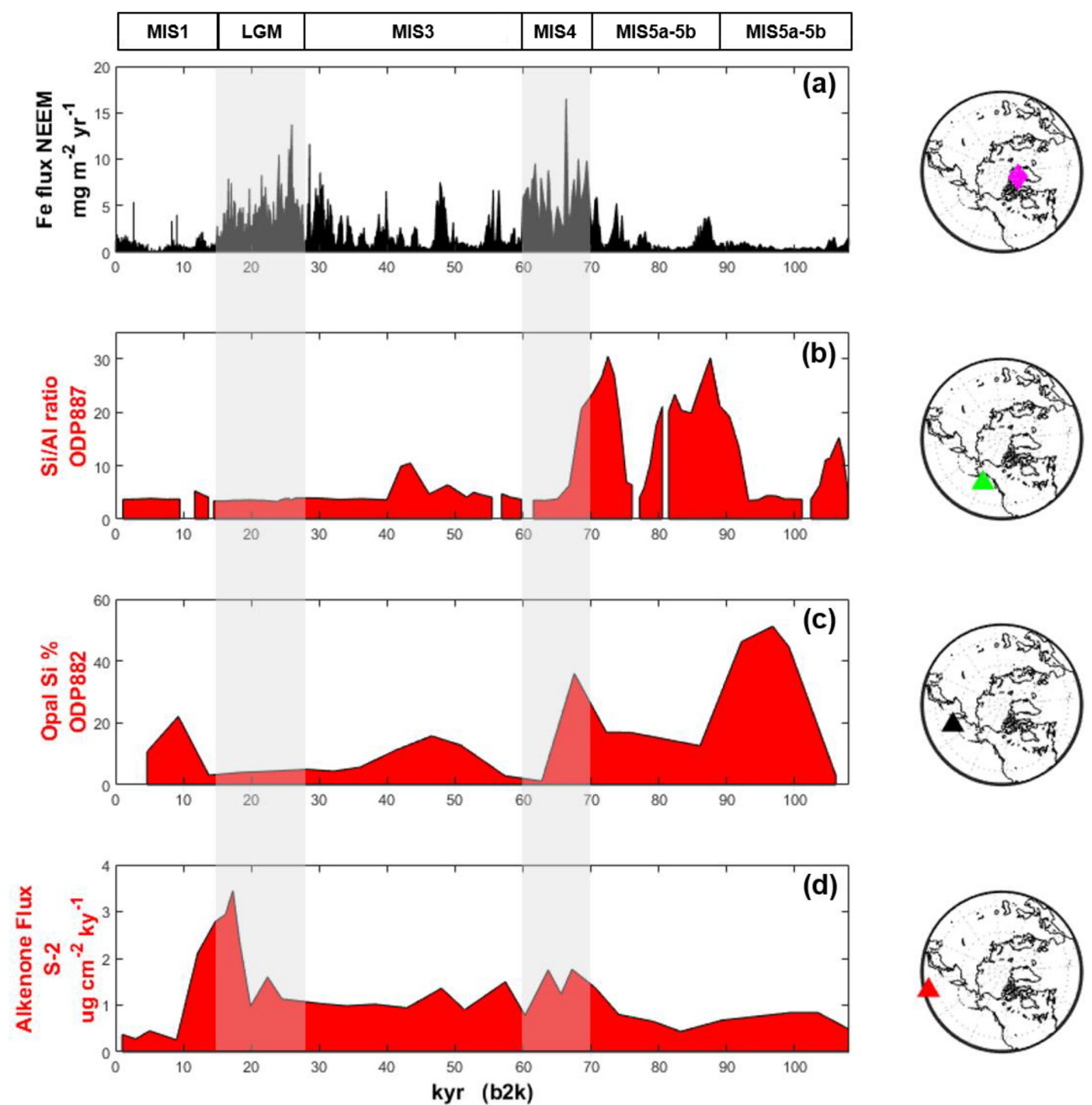

Figure 4. Comparison between Fe fluxes (black line, a) from NEEM (pink diamond; this work) and marine productivity (red line, b) from ODP887 in the eastern subarctic Pacific (green triangle; McDonald et al., 1999), ODP882 (red line, c) in the western subarctic Pacific (black triangle; Haug et al., 1995) and S-2 (red line, d) in the midlatitude North Pacific (red triangle; Amo and Minagawa, 2003). Due to their limited temporal extension, productivity records from SO202-07-6 and SO202-07-26 are not discussed in this figure and are instead shown in Fig. 5.

above a hydrographic boundary at $1500-2000 \mathrm{~m}$ (Kohfeld and Chase, 2017). Water stratification led to the minimal input of nutrients to the surface ocean, leading the system towards a major nutrient limitation (Kienast et al., 2004; Ren et al., 2015). Among the several possible reasons that can explain the increase in water stratification in the glacial North Pacific, we propose two hypotheses. The first relies on the glacial closure of the Bering Strait that reduced the freshwater export from the Pacific Ocean to the Atlantic, retaining more freshwater in the North Pacific (Talley, 2008). The second involves sea ice formation. When sea ice forms, in the Okhotsk and Bering seas, brine rejection occurs, increasing water density and creating the more saline and denser North Pacific Intermediate Water (NPIW). When the wind blows the sea ice away from where it was originally formed, brine rejection can further proceed at the same location following the formation of new sea ice. The continuous brine rejection promotes the freshening of surface waters and strengthens water stratification (Costa et al., 2018).

An additional explanation for the observed lower productivity during glacial periods arises from the higher extent of perennial sea ice that might have played a role in creating a physical barrier between the atmosphere and the marine environment, reducing the amount of available sunlight and the direct deposition of bioavailable Fe on the seawater surface (Kienast et al., 2004; Méheust et al., 2018). Marine sediment records, collected in the eastern and western subarctic Pacific and in the Bering Sea, have shown extended spring ice cover during the LGM (Méheust et al., 2018; Méheust et al., 2016) when the Fe fluxes were at their maxima. The progressive decrease in perennial sea ice coverage recorded after the LGM led to an increase in the marine productivity 

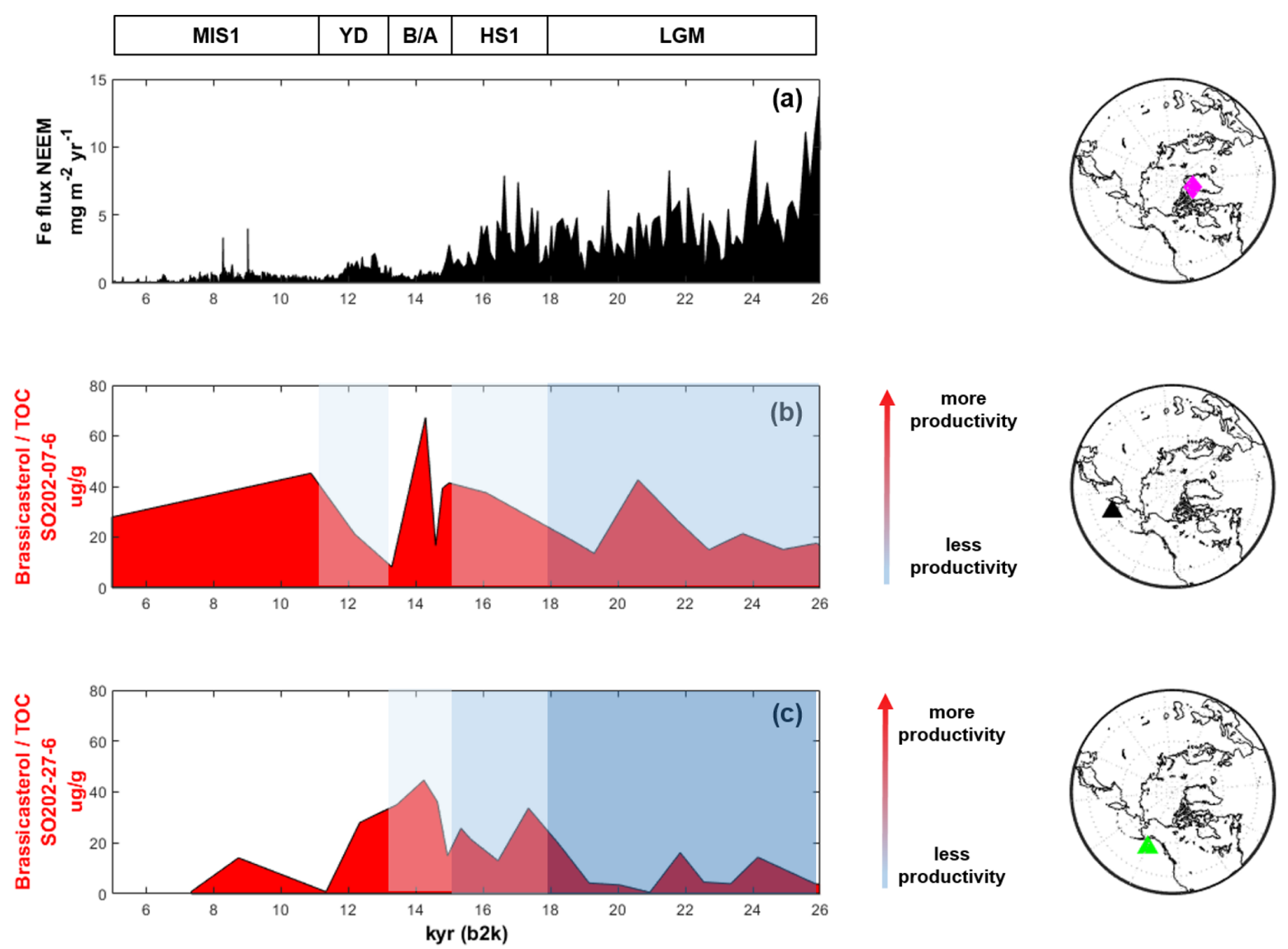

Figure 5. Relationship between the Fe flux in the NEEM core and MPP in subarctic Pacific Ocean over the last 26 kyr, where a higher brassicasterol-total organic carbon ratio represents an increase in productivity. Sea ice data are from Meheust et al. (2018): prevalently extended sea ice (dark blue rectangle), prevalently marginal sea ice (blue rectangle), prevalently variable sea ice (light blue rectangle) and prevalently ice-free (white rectangle). The Fe flux record (black line, a), productivity in the eastern subarctic Pacific Ocean (SO202-07-6, red line, b) and productivity in the western subarctic Pacific Ocean (S0202-27-6, red line, c) are also shown. Productivity pulses were recorded when sea ice changed its conditions towards ice-free conditions. YD stands for Younger Dryas, B/A stands for Bølling-Allerød, HS1 stands for Heinrich Stadial 1 and LGM stands for Last Glacial Maximum.

(Fig. 5), with a maximum during the Bølling-Allerød (B/A) warm event $(\approx 13-15 \mathrm{kyr}$ ago $)$. The possible relevance of sea ice in modulating MPP at the highest latitude of the Pacific Ocean during the LGM is strengthened by a marine sediment record collected in the midlatitude North Pacific (Amo and Minagawa, 2003), which, because of its southernmost location, did not experience any sea ice condition. During the LGM, contrarily to what is observed in the subarctic Pacific, a prominent maximum in marine productivity was recorded, suggesting that $\mathrm{Fe}$ could have triggered an important phytoplankton response (Fig. 4d). The Fe sensitivity of the midlatitude North Pacific is confirmed during the Holocene, when the Fe fluxes were at their minima and the productivity, expressed as MAR (mass accumulation rate) $\mathrm{C}_{37}$ alkenone $\left(\mu \mathrm{g} \mathrm{cm}^{-2} \mathrm{kyr}^{-1}\right.$ ), was at its lowest level. A plausible explanation is that stratified waters did not characterize this region during the last glacial period and, thus, it was not affected by the limitation of major nutrients. Unfortunately, neither FB- $\delta^{15} \mathrm{~N}$ nor information about water stratification is available for this record.

However, there might be other reasons that could explain the strengthening in MPP during the B/A warm period in the subarctic North Pacific. Among them, we propose the increase in the sea level that inundated previously exposed lands which might have entrained iron and other nutrients to the marine ecosystem (Davies et al., 2011), or changes in the oceanic circulation (McManus et al., 2004). Indeed, at the onset of the $\mathrm{B} / \mathrm{A}$ event, the meridional overturning circulation rapidly accelerated, and this might have produced an upward displacement of the nutrient-rich North Pacific Deep Water towards intermediate depths, promoting an injection of nutrients to surface waters and enhancing marine productivity.

These additional explanations shed light on the marginal role that atmospheric Fe fertilization had in promoting MPP 
in the subarctic Pacific Ocean, as other players might have had a more significant impact (Kohfeld and Chase, 2017).

\subsubsection{From $108 \mathrm{ka}$ to the LGM}

According to the available records, marine productivity changed heterogeneously in the Pacific Ocean during the last glacial period (Fig. 4).

It is challenging to state, with a high degree of confidence, whether or not Fe fertilization triggered a phytoplankton bloom in the HNLC subarctic North Pacific. This is due to the different responses that the western and the eastern side of the subarctic North Pacific showed with respect to the atmospheric Fe supply (Fig. 4). In the eastern subarctic Pacific, the increase in the eolian $\mathrm{Fe}$ fluxes was mirrored by a phytoplankton response during the MIS 5.2 and the MIS 5MIS 4 transition. The subsequent decrease in MPP during the MIS 4 suggests that the prolonged Fe supply during the coldest stadial might have led the ecosystem towards the limitation of other nutrients (Kienast et al., 2004), following the same mechanisms described in the previous section. The enhanced water stratification during those periods, as suggested by stable oxygen isotope ratios in planktonic foraminifera (Zahn et al., 1991), did not allow a supply of macronutrients from below the mixed layer. Thus, the additional atmospheric Fe supply had little effect on phytoplankton productivity, suggesting their growth was likely limited by the lack of major nutrients (Kienast et al., 2004). In the western subarctic Pacific, the increase in productivity was also recorded in periods with low atmospheric $\mathrm{Fe}$ fluxes (e.g., from 100 to $90 \mathrm{ka}$ at ODP882), strengthening the hypothesis that other influences (e.g., meltwater inputs, continental margin supply and sea ice) had a more relevant role (Kienast et al., 2004; Lam and Bishop, 2008) than the atmospheric Fe supply.

Contrary to what was observed in the subarctic Pacific, the S-2 sediment core collected in the midlatitude North Pacific (Amo and Minagawa, 2003) showed a marked increase in MPP during MIS 4 and the overall last glacial period when the Fe fluxes were higher (Fig. 4). MPP in the midlatitude North Pacific might have been more sensitive to the atmospheric Fe supply, suggesting that the high degree of upperocean stratification that characterized the subarctic region of the Pacific Ocean did not affect the midlatitude North Pacific, allowing for a continuous supply of macronutrients. The observed increase in dust transport (and Fe deposition) could have then stimulated marine productivity (Kienast et al., 2004).

\section{Conclusions and future perspectives}

In this study, we provided a high temporal resolution $\mathrm{Fe}$ record from mineral dust input retrieved from the NEEM ice core. Through the comparison with other available $\mathrm{Fe}$ records, we observed that Fe fluxes were higher in Greenland than in Antarctica. The greatest difference between the
Arctic and Antarctic records occurred during MIS4, when Fe fluxes in NEEM were 1.5 times higher than during the LGM, whereas, in TD and EDC, they were lower. To explain this behavior, we advanced two hypotheses (i.e., change in the atmospheric circulation or additional dust sources that reached Greenland), although more detailed investigations are needed.

Merging our record with marine productivity data, we found that a link between $\mathrm{Fe}$ transport and ocean productivity holds in the midlatitude North Pacific, indicating that this area might be sensitive to the atmospheric Fe supply. On the contrary, in the subarctic Pacific, we did not find any overwhelming evidence that the increase in the atmospheric Fe fluxes triggered a phytoplankton response. This indicates that other players, such as sea ice and increased water stratification during the coldest periods, had a more relevant role in modulating MPP in the HNLC region of the North Pacific on a millennial timescale.

This study provides an upper limit for estimating the potentially bioavailable Fe supplied to marine phytoplankton in the North Pacific region; however, additional studies should focus on analyzing the labile and bioavailable $\mathrm{Fe}$ fractions to constrain the realistic Fe supply and response of the marine ecosystem.

Data availability. Data will be published on PANGAEA in April 2021.

Author contributions. FB wrote the paper. FB, AS and CB designed the research. JG, CT and GC performed the analyses. PV contributed to the interpretation of the results.

Competing interests. The authors declare that they have no conflict of interest.

Acknowledgements. We sincerely thank everyone involved in the logistics, drilling operations, ice core processing and sample collection. NEEM is directed and organized by the Center of Ice and Climate at the Niels Bohr Institute and the US NSF Office of Polar Programs, and it is supported by funding agencies and institutions in Belgium (FNRS-CFB and FWO), Canada (NRCan/GSC), China (CAS), Denmark (FIST), France (IPEV, CNRS/INSU, CEA and ANR), Germany (AWI), Iceland (RannIs), Japan (NIPR), South Korea (KOPRI), the Netherlands (NWO/ALW), Sweden (VR), Switzerland (SNF), the UK (NERC) and the USA (US NSF, Office of Polar Programs).

We are grateful to the three anonymous reviewers and the editor, Alberto Reyes, all of whom contributed to the overall improvement of the paper. 
Financial support. This research has been supported by the European Union's Seventh Framework programme (FP7/2007-2013) under grant agreement no. 243908, "Past4Future. Climate change Learning from the past climate".

Review statement. This paper was edited by Alberto Reyes and reviewed by three anonymous referees.

\section{References}

Albani, S., Delmonte, B., Maggi, V., Baroni, C., Petit, J.-R., Stenni, B., Mazzola, C., and Frezzotti, M.: Interpreting last glacial to Holocene dust changes at Talos Dome (East Antarctica): implications for atmospheric variations from regional to hemispheric scales, Clim. Past, 8, 741-750, https://doi.org/10.5194/cp-8-7412012, 2012.

Amo, M. and Minagawa, M.: Sedimentary record of marine and terrigenous organic matter delivery to the Shatsky Rise, western North Pacific, over the last 130 kyr, Org. Geochem., 34, 12991312, 2003.

Baccolo, G., Delmonte, B., Albani, S., Baroni, C., Cibin, G., Frezzotti, M., Hampai, D., Marcelli, A., Revel, M., and Salvatore, M.: Regionalization of the atmospheric dust cycle on the periphery of the East Antarctic ice sheet since the last glacial maximum, Geochem. Geophy. Geosy. 19, 3540-3554, 2018.

Basile, I., Grousset, F. E., Revel, M., Petit, J. R., Biscaye, P. E., and Barkov, N. I.: Patagonian origin of glacial dust deposited in East Antarctica (Vostok and Dome C) during glacial stages 2, 4 and 6, Earth Planet. Sci. Lett., 146, 573-589, 1997.

Boyd, P., Muggli, D., Varela, D., Goldblatt, R., Chretien, R., Orians, K., and Harrison, P.: In vitro iron enrichment experiments in the NE subarctic Pacific, Mar. Ecol. Progr. Ser., 136, 179-193, 1996.

Burgay, F., Erhardt, T., Lunga, D. D., Jensen, C. M., Spolaor, A., Vallelonga, P., Fischer, H., and Barbante, C.: $\mathrm{Fe}^{2+}$ in ice cores as a new potential proxy to detect past volcanic eruptions, Sci. Total Environ., 654, 1110-1117, 2019.

Costa, K. M., McManus, J. F., and Anderson, R. F.: Paleoproductivity and Stratification Across the Subarctic Pacific Over GlacialInterglacial Cycles, Paleoceanogr. Paleoclimatol., 33, 914-933, 2018.

Davies, M., Mix, A., Stoner, J., Addison, J., Jaeger, J., Finney, B., and Wiest, J.: The deglacial transition on the southeastern Alaska Margin: Meltwater input, sea level rise, marine productivity, and sedimentary anoxia, Paleoceanography, 26, PA2223, https://doi.org/10.1029/2010PA002051, 2011.

Delmonte, B., Andersson, P., Schöberg, H., Hansson, M., Petit, J., Delmas, R., Gaiero, D. M., Maggi, V., and Frezzotti, M.: Geographic provenance of aeolian dust in East Antarctica during Pleistocene glaciations: preliminary results from Talos Dome and comparison with East Antarctic and new Andean ice core data, Quaternary Sci. Rev., 29, 256-264, 2010a.

Delmonte, B., Baroni, C., Andersson, P. S., Schoberg, H., Hansson, M., Aciego, S., Petit, J.-R., Albani, S., Mazzola, C., Maggi, V., and Frezzotti, M.: Aeolian dust in the Talos Dome ice core (East Antarctica, Pacific/Ross Sea sector): Victoria Land versus remote sources over the last two climate cycles, J. Quaternary Sci., 25, 1327-1337, 2010b.
Du, Z., Xiao, C., Mayewski, P. A., Handley, M. J., Li, C., Ding, M., Liu, J., Yang, J., and Liu, K.: The iron records and its sources during 1990-2017 from the Lambert Glacial Basin shallow ice core, East Antarctica, Chemosphere, 251, 126399, https://doi.org/10.1016/j.chemosphere.2020.126399, 2020.

Duggen, S., Olgun, N., Croot, P., Hoffmann, L., Dietze, H., Delmelle, P., and Teschner, C.: The role of airborne volcanic ash for the surface ocean biogeochemical iron-cycle: a review, Biogeosciences, 7, 827-844, https://doi.org/10.5194/bg-7-8272010, 2010.

Duprat, L. P., Bigg, G. R., and Wilton, D. J.: Enhanced Southern Ocean marine productivity due to fertilization by giant icebergs, Nat. Geosci., 9, 219, https://doi.org/10.1038/ngeo2633, 2016.

Edwards, R., Sedwick, P. N., Morgan, V., Boutron, C. F., and Hong, S.: Iron in ice cores from Law Dome, East Antarctica: implications for past deposition of aerosol iron, Ann. Glaciol., 27, 365370, 1998.

Edwards, R., Sedwick, P., Morgan, V., and Boutron, C.: Iron in ice cores from Law Dome: A record of atmospheric iron deposition for maritime East Antarctica during the Holocene and Last Glacial Maximum, Geochem. Geophy. Geosy., 7, Q12Q01, https://doi.org/10.1029/2006GC001307, 2006.

Edwards, R. P. R.: Iron in modern and ancient East Antarctic snow: Implications for phytoplankton production in the Southern Ocean, PhD thesis, Institute of Antarctic and Southern Ocean Studies, University of Tasmania, Hobart, Australia, 1999.

Fuhrer, K., Wolff, E. W., and Johnsen, S. J.: Timescales for dust variability in the Greenland Ice Core Project (GRIP) ice core in the last 100000 years, J. Geophys. Res.-Atmos., 104, 31043$31052,1999$.

Gaspari, V., Barbante, C., Cozzi, G., Cescon, P., Boutron, C., Gabrielli, P., Capodaglio, G., Ferrari, C., Petit, J., and Delmonte, B.: Atmospheric iron fluxes over the last deglaciation: Climatic implications, Geophys. Res. Lett., 33, L03704, https://doi.org/10.1029/2005GL024352, 2006.

Han, C., Do Hur, S., Han, Y., Lee, K., Hong, S., Erhardt, T., Fischer, H., Svensson, A. M., Steffensen, J. P., and Vallelonga, P.: Highresolution isotopic evidence for a potential Saharan provenance of Greenland glacial dust, Sci. Rep.-UK, 8, 1-9, 2018.

Haug, G., Maslin, M., Sarnthein, M., Stax, R., and Tiedemann, R.: 20. Evolution of Northwest Pacific Sedimentation Patterns Since 6 MA (Site 882), 293, in: Proceedings of the Ocean Drilling Program, Scientific Results, Vol. 145, https://doi.org/10.2973/odp.proc.sr.145.115.1995, 1995.

Hiscock, W. T., Fischer, H., Bigler, M., Gfeller, G., Leuenberger, D., and Mini, O.: Continuous flow analysis of labile iron in icecores, Environ. Sci. Technol., 47, 4416-4425, 2013.

Jouzel, J., Waelbroeck, C., Malaize, B., Bender, M., Petit, J., Stievenard, M., Barkov, N., Barnola, J., King, T., and Kotlyakov, V.: Climatic interpretation of the recently extended Vostok ice records, Clim. Dyn., 12, 513-521, 1996.

Kang, S., Roberts, H. M., Wang, X., An, Z., and Wang, M.: Mass accumulation rate changes in Chinese loess during MIS 2, and asynchrony with records from Greenland ice cores and North Pacific Ocean sediments during the Last Glacial Maximum, Aeolian Res., 19, 251-258, 2015.

Kawahata, H., Okamoto, T., Matsumoto, E., and Ujiie, H.: Fluctuations of eolian flux and ocean productivity in the mid-latitude 
North Pacific during the last 200 kyr, Quaternary Sci. Rev., 19, 1279-1291, 2000.

Kienast, S. S., Hendy, I. L., Crusius, J., Pedersen, T. F., and Calvert, S. E.: Export production in the subarctic North Pacific over the last $800 \mathrm{kyr}$ : No evidence for iron fertilization?, J. Oceanogr., 60, 189-203, 2004.

Koffman, B. G., Handley, M. J., Osterberg, E. C., Wells, M. L., and Kreutz, K. J.: Dependence of ice-core relative trace-element concentration on acidification, J. Glaciol., 60, 103-112, 2014.

Kohfeld, K. E. and Chase, Z.: Temporal evolution of mechanisms controlling ocean carbon uptake during the last glacial cycle, Earth Planet. Sci. Lett., 472, 206-215, 2017.

Köhler, P., Nehrbass-Ahles, C., Schmitt, J., Stocker, T. F., and Fischer, H.: A $156 \mathrm{kyr}$ smoothed history of the atmospheric greenhouse gases $\mathrm{CO}_{2}, \mathrm{CH}_{4}$, and $\mathrm{N}_{2} \mathrm{O}$ and their radiative forcing, Earth Syst. Sci. Data, 9, 363-387, https://doi.org/10.5194/essd9-363-2017, 2017.

Lam, P. and Bishop, J. K. B.: The continental margin is a key source of iron to the HNLC North Pacific Ocean, Geophys. Res. Lett., 35, L07608, https://doi.org/10.1029/2008GL033294, 2008.

Lambert, F., Delmonte, B., Petit, J.-R., Bigler, M., Kaufmann, P. R., Hutterli, M. A., Stocker, T. F., Ruth, U., Steffensen, J. P., and Maggi, V.: Dust-climate couplings over the past 800000 years from the EPICA Dome C ice core, Nature, 452, 616-619, https://doi.org/10.1038/nature06763, 2008.

Lambert, F., Tagliabue, A., Shaffer, G., Lamy, F., Winckler, G., Farias, L., Gallardo, L., and De Pol-Holz, R.: Dust fluxes and iron fertilization in Holocene and Last Glacial Maximum climates, Geophys. Res. Lett., 42, 6014-6023, 2015.

Langmann, B., Zakšek, K., Hort, M., and Duggen, S.: Volcanic ash as fertiliser for the surface ocean, Atmos. Chem. Phys., 10, 38913899, https://doi.org/10.5194/acp-10-3891-2010, 2010.

Löfverström, M., Caballero, R., Nilsson, J., and Kleman, J.: Evolution of the large-scale atmospheric circulation in response to changing ice sheets over the last glacial cycle, Clim. Past, 10, 1453-1471, https://doi.org/10.5194/cp-10-1453-2014, 2014.

Lupker, M., Aciego, S. M., Bourdon, B., Schwander, J., and Stocker, T.: Isotopic tracing ( $\mathrm{Sr}, \mathrm{Nd}, \mathrm{U}$ and $\mathrm{Hf}$ ) of continental and marine aerosols in an 18th century section of the Dye-3 ice core (Greenland), Earth Planet. Sci. Lett., 295, 277-286, 2010.

Lüthi, D., Le Floch, M., Bereiter, B., Blunier, T., Barnola, J.-M., Siegenthaler, U., Raynaud, D., Jouzel, J., Fischer, H., and Kawamura, K.: High-resolution carbon dioxide concentration record 650000-800 000 years before present, Nature, 453, 379-382, 2008.

Mahowald, N. M., Yoshioka, M., Collins, W. D., Conley, A. J., Fillmore, D. W., and Coleman, D. B.: Climate response and radiative forcing from mineral aerosols during the last glacial maximum, pre-industrial, current and doubledcarbon dioxide climates, Geophys. Res. Lett., 33, L20705, https://doi.org/10.1029/2006GL026126, 2006.

Mahowald, N. M., Engelstaedter, S., Luo, C., Sealy, A., Artaxo, P., Benitez-Nelson, C., Bonnet, S., Chen, Y., Chuang, P. Y., Cohen, D. D., Dulac, F., Herut, B., Johansen, A. M., Kubilay, N., Losno, R., Maenhaut, W., Paytan, A., Prospero, J. M., Shank, L. M., and Siefert, R. L.: Atmospheric Iron Deposition: Global Distribution, Variability, and Human Perturbations, Annu. Rev. Mar. Sci., 1, 245-278, 2008.
Manabe, S. and Broccoli, A.: The influence of continental ice sheets on the climate of an ice age, J. Geophys. Res.-Atmos., 90, 21672190, 1985.

Martin, J. H., Gordon, R. M., and Fitzwater, S. E.: Iron in Antarctic waters, Nature, 345, 156-158, 1990.

Martínez-Garcia, A., Rosell-Melé, A., Jaccard, S. L., Geibert, W., Sigman, D. M., and Haug, G. H.: Southern Ocean dust-climate coupling over the past four million years, Nature, 476, 312-316, https://doi.org/10.1038/nature10310, 2011.

Martínez-García, A., Sigman, D. M., Ren, H., Anderson, R. F., Straub, M., Hodell, D. A., Jaccard, S. L., Eglinton, T. I., and Haug, G. H.: Iron fertilization of the Subantarctic Ocean during the last ice age, Science, 343, 1347-1350, 2014.

Mayewski, P. A., Meeker, L. D., Whitlow, S., Twickler, M. S., Morrison, M. C., Bloomfield, P., Bond, G., Alley, R. B., Gow, A. J., and Meese, D. A.: Changes in atmospheric circulation and ocean ice cover over the North Atlantic during the last 41,000 years, Science, 263, 1747-1751, 1994.

McDonald, D., Pedersen, T., and Crusius, J.: Multiple late Quaternary episodes of exceptional diatom production in the Gulf of Alaska, Deep Sea Res. Pt. II, 46, 2993-3017, 1999.

McManus, J. F., Francois, R., Gherardi, J.-M., Keigwin, L. D., and Brown-Leger, S.: Collapse and rapid resumption of Atlantic meridional circulation linked to deglacial climate changes, Nature, 428, 834-837, 2004.

Méheust, M., Stein, R., Fahl, K., Max, L., and Riethdorf, J.-R.: High-resolution IP 25-based reconstruction of sea-ice variability in the western North Pacific and Bering Sea during the past 18,000 years, Geo-Mar. Lett., 36, 101-111, 2016.

Méheust, M., Stein, R., Fahl, K., and Gersonde, R.: Sea-ice variability in the subarctic North Pacific and adjacent Bering Sea during the past $25 \mathrm{ka}$ : new insights from IP 25 and U k' 37 proxy records, Arktos, 4, 1-19, https://doi.org/10.1007/s41063018-0043-1, 2018.

Miller, R. and Tegen, I.: Climate response to soil dust aerosols, J. Climate, 11, 3247-3267, 1998.

Müller, J., Wagner, A., Fahl, K., Stein, R., Prange, M., and Lohmann, G.: Towards quantitative sea ice reconstructions in the northern North Atlantic: A combined biomarker and numerical modelling approach, Earth Planet. Sci. Lett., 306, 137-148, 2011.

North Greenland Ice Core Project Members: 50 year means of oxygen isotope data from ice core NGRIP, PANGAEA, https://doi.org/10.1594/PANGAEA.586886, 2007.

Olgun, N., Duggen, S., Croot, P. L., Delmelle, P., Dietze, H., Schacht, U., Oskarsson, N., Siebe, C., Auer, A., and GarbeSchönberg, D.: Surface ocean iron fertilization: the role of subduction zone and hotspot volcanic ash and fluxes into the Pacific Ocean, Global Biogeochem. Cy., 25, GB4001, https://doi.org/10.1029/2009GB003761, 2011.

Rasmussen, S. O., Abbott, P. M., Blunier, T., Bourne, A. J., Brook, E., Buchardt, S. L., Buizert, C., Chappellaz, J., Clausen, H. B., Cook, E., Dahl-Jensen, D., Davies, S. M., Guillevic, M., Kipfstuhl, S., Laepple, T., Seierstad, I. K., Severinghaus, J. P., Steffensen, J. P., Stowasser, C., Svensson, A., Vallelonga, P., Vinther, B. M., Wilhelms, F., and Winstrup, M.: A first chronology for the North Greenland Eemian Ice Drilling (NEEM) ice core, Clim. Past, 9, 2713-2730, https://doi.org/10.5194/cp-92713-2013, 2013. 
Ren, H., Studer, A. S., Serno, S., Sigman, D. M., Winckler, G., Anderson, R. F., Oleynik, S., Gersonde, R., and Haug, G. H.: Glacial-to-interglacial changes in nitrate supply and consumption in the subarctic North Pacific from microfossil-bound $\mathrm{N}$ isotopes at two trophic levels, Paleoceanography, 30, 1217-1232, 2015.

Röthlisberger, R., Bigler, M., Wolff, E. W., Joos, F., Monnin, E., and Hutterli, M. A.: Ice core evidence for the extent of past atmospheric $\mathrm{CO}_{2}$ change due to iron fertilisation, Geophys. Res. Lett., 31, L16207, https://doi.org/10.1029/2004GL020338, 2004.

Ruth, U.: Dust concentration in the NGRIP ice core, PANGAEA, https://doi.org/10.1594/PANGAEA.587836, 2007.

Ruth, U., Bigler, M., Röthlisberger, R., Siggaard-Andersen, M. L., Kipfstuhl, S., Goto-Azuma, K., Hansson, M. E., Johnsen, S. J., Lu, H., and Steffensen, J. P.: Ice core evidence for a very tight link between North Atlantic and east Asian glacial climate, Geophys. Res. Lett., 34, L03706, https://doi.org/10.1029/2006GL027876, 2007.

Sachs, J. P. and Anderson, R. F.: Increased productivity in the subantarctic ocean during Heinrich events, Nature, 434, 1118-1121, 2005.

Schepanski, K.: Transport of mineral dust and its impact on climate, Geosciences, 8, 151, https://doi.org/10.3390/geosciences8050151, 2018.

Schüpbach, S., Fischer, H., Bigler, M., Erhardt, T., Gfeller, G., Leuenberger, D., Mini, O., Mulvaney, R., Abram, N. J., and Fleet, L.: Greenland records of aerosol source and atmospheric lifetime changes from the Eemian to the Holocene, Nat. Commun., 9, 1476, https://doi.org/10.1038/s41467-018-03924-3, 2018.

Serno, S., Winckler, G., Anderson, R. F., Hayes, C. T., McGee, D., Machalett, B., Ren, H., Straub, S. M., Gersonde, R., and Haug, G. H.: Eolian dust input to the Subarctic North Pacific, Earth Planet. Sci. Lett., 387, 252-263, 2014.

Serno, S., Winckler, G., Anderson, R. F., Maier, E., Ren, H., Gersonde, R., and Haug, G. H.: Comparing dust flux records from the Subarctic North Pacific and Greenland: Implications for atmospheric transport to Greenland and for the application of dust as a chronostratigraphic tool, Paleoceanography, 30, 583-600, 2015.

Shoenfelt, E. M., Sun, J., Winckler, G., Kaplan, M. R., Borunda, A. L., Farrell, K. R., Moreno, P. I., Gaiero, D. M., Recasens, C., and Sambrotto, R. N.: High particulate iron (II) content in glacially sourced dusts enhances productivity of a model diatom, Sci. Adv., 3, e1700314, https://doi.org/10.1126/sciadv.1700314, 2017.

Shoenfelt, E. M., Winckler, G., Lamy, F., Anderson, R. F., and Bostick, B. C.: Highly bioavailable dust-borne iron delivered to the Southern Ocean during glacial periods, P. Natl. Acad. Sci. USA, 115, 11180-11185, 2018.

Smetacek, V., Klaas, C., Strass, V. H., Assmy, P., Montresor, M., Cisewski, B., Savoye, N., Webb, A., d'Ovidio, F., and Arrieta, J. M.: Deep carbon export from a Southern Ocean iron-fertilized diatom bloom, Nature, 487, 313-319, 2012.

Spolaor, A., Vallelonga, P., Cozzi, G., Gabrieli, J., Varin, C., Kehrwald, N., Zennaro, P., Boutron, C., and Barbante, C.: Iron speciation in aerosol dust influences iron bioavailability over glacial-interglacial timescales, Geophys. Res. Lett., 40, 1618$1623,2013$.
Sun, W., Shen, J., Yu, S.-Y., Long, H., Zhang, E., Liu, E., and Chen, R.: A lacustrine record of East Asian summer monsoon and atmospheric dust loading since the last interglaciation from Lake Xingkai, northeast China, Quaternary Res., 89, 270-280, 2018.

Svensson, A., Biscaye, P. E., and Grousset, F. E.: Characterization of late glacial continental dust in the Greenland Ice Core Project ice core, J. Geophys. Res.-Atmos., 105, 4637-4656, 2000.

Talley, L. D.: Freshwater transport estimates and the global overturning circulation: Shallow, deep and throughflow components, Prog. Oceanogr., 78, 257-303, 2008.

Tsuda, A., Takeda, S., Saito, H., Nishioka, J., Nojiri, Y., Kudo, I., Kiyosawa, H., Shiomoto, A., Imai, K., and Ono, T.: A mesoscale iron enrichment in the western subarctic Pacific induces a large centric diatom bloom, Science, 300, 958-961, 2003.

Tulenko, J. P., Lofverstrom, M., and Briner, J. P.: Ice sheet influence on atmospheric circulation explains the patterns of Pleistocene alpine glacier records in North America, Earth Planet. Sci. Lett., 534, 116115, https://doi.org/10.1016/j.epsl.2020.116115, 2020.

Vallelonga, P., Van de Velde, K., Candelone, J.-P., Morgan, V., Boutron, C., and Rosman, K.: The lead pollution history of Law Dome, Antarctica, from isotopic measurements on ice cores: 1500 AD to 1989 AD, Earth Planet. Sci. Lett., 204, 291-306, 2002.

Vallelonga, P., Barbante, C., Cozzi, G., Gabrieli, J., Schüpbach, S., Spolaor, A., and Turetta, C.: Iron fluxes to Talos Dome, Antarctica, over the past $200 \mathrm{kyr}$, Clim. Past, 9, 597-604, https://doi.org/10.5194/cp-9-597-2013, 2013.

Watanabe, O., Jouzel, J., Johnsen, S., Parrenin, F., Shoji, H., and Yoshida, N.: Homogeneous climate variability across East Antarctica over the past three glacial cycles, Nature, 422, 509512, 2003.

Wolff, E. W., Fischer, H., Fundel, F., Ruth, U., Twarloh, B., Littot, G. C., Mulvaney, R., Röthlisberger, R., De Angelis, M., and Boutron, C. F.: Southern Ocean sea-ice extent, productivity and iron flux over the past eight glacial cycles, Nature, 440, 491-496, 2006.

Xiao, C., Du, Z., Handley, M. J., Mayewski, P. A., Cao, J., Schüpbach, S., Zhang, T., Petit, J.-R., Li, C., and Han, Y.: Iron in the NEEM ice core relative to Asian loess records over the last glacial-interglacial cycle, Natl. Sci. Rev., nwaa144, https://doi.org/10.1093/nsr/nwaa144, 2020.

Xiao, J., An, Z., Liu, T., Inouchi, Y., Kumai, H., Yoshikawa, S., and Kondo, Y.: East Asian monsoon variation during the last 130,000 years: evidence from the Loess Plateau of central China and Lake Biwa of Japan, Quaternary Sci. Rev., 18, 147-157, 1999.

Yoon, J.-E., Yoo, K.-C., Macdonald, A. M., Yoon, H.-I., Park, K.T., Yang, E. J., Kim, H.-C., Lee, J. I., Lee, M. K., Jung, J., Park, J., Lee, J., Kim, S., Kim, S.-S., Kim, K., and Kim, I.-N.: Reviews and syntheses: Ocean iron fertilization experiments past, present, and future looking to a future Korean Iron Fertilization Experiment in the Southern Ocean (KIFES) project, Biogeosciences, 15, 5847-5889, https://doi.org/10.5194/bg-155847-2018, 2018.

Young, R., Carder, K., Betzer, P., Costello, D., Duce, R., DiTullio, G., Tindale, N., Laws, E., Uematsu, M., and Merrill, J.: Atmospheric iron inputs and primary productivity: Phytoplankton responses in the North Pacific, Global Biogeochem. Cy., 5, 119134, 1991. 
Yung, Y. L., Lee, T., Wang, C.-H., and Shieh, Y.-T.: Dust: A diagnostic of the hydrologic cycle during the Last Glacial Maximum, Science, 271, 962-963, 1996.

Zahn, R., Pedersen, T. F., Bornhold, B. D., and Mix, A. C.: Water mass conversion in the glacial subarctic Pacific $\left(54^{\circ} \mathrm{N}, 148^{\circ} \mathrm{W}\right)$ : Physical constraints and the benthic-planktonic stable isotope record, Paleoceanography, 6, 543-560, 1991.

Zhang, X.-Y., Gong, S., Zhao, T., Arimoto, R., Wang, Y., and Zhou, $Z$.: Sources of Asian dust and role of climate change versus desertification in Asian dust emission, Geophys. Res. Lett., 30, 2272, https://doi.org/10.1029/2003GL018206, 2003.
Zhang, X., Han, Y., Sun, Y., Cao, J., and An, Z.: Asian dust, eolian iron and black carbon-Connections to climate changes, in: Late Cenozoic Climate Change in Asia, Springer, Dordrecht, the Netherlands, https://doi.org/10.1007/978-94-007-7817-7_4, 2014. 